Article

\title{
Phytochemical Profile, Antimicrobial, Cytotoxic, and Antioxidant Activities of Fresh and Air-Dried Satureja nabateorum Essential Oils
}

\author{
Nawaf Al-Maharik ${ }^{1, *}$ and Nidal Jaradat ${ }^{2, *(D)}$ \\ 1 Department of Chemistry, Faculty of Sciences, An-Najah National University, Nablus P6028820, Palestine \\ 2 Department of Pharmacy, Faculty of Medicine and Health Sciences, An-Najah National University, \\ Nablus P6028820, Palestine \\ * Correspondence: n.maharik@najah.edu (N.A.-M.); nidaljaradat@najah.edu (N.J.)
}

Citation: Al-Maharik, N.; Jaradat, N. Phytochemical Profile, Antimicrobial, Cytotoxic, and Antioxidant Activities of Fresh and Air-Dried Satureja nabateorum Essential Oils. Molecules 2022, 27, 125. https://doi.org/ 10.3390/molecules 27010125 Academic Editors: Asta Judžentienè and Kristina Ložienè

Received: 13 November 2021 Accepted: 23 December 2021

Published: 26 December 2021

Publisher's Note: MDPI stays neutral with regard to jurisdictional claims in published maps and institutional affiliations.

Copyright: (C) 2021 by the authors. Licensee MDPI, Basel, Switzerland. This article is an open access article distributed under the terms and conditions of the Creative Commons Attribution (CC BY) license (https:// creativecommons.org/licenses/by/ $4.0 /)$.

\begin{abstract}
Satureja nabateorum (Danin and Hedge) Bräuchler is a perennial herb in the Lamiaceae family that was discovered and classified in 1998. This green herb is restricted to the mountains overlooking the Dead Sea, specifically in Jordan's southwest, the Edom mountains, and the Tubas mountains in Palestine. Gas chromatography-mass spectrometry (GC-MS) analysis of essential oil (EO) of air-dried and fresh S. nabateorum resulted in the identification of 30 and 42 phytochemicals accounting for 99.56 and $98.64 \%$ of the EO, respectively. Thymol $(46.07 \pm 1.1$ and $40.64 \pm 1.21 \%)$ was the major compound, followed by its biosynthetic precursors $\gamma$-terpinene $(21.15 \pm 1.05 \%$ and $20.65 \pm 1.12 \%)$, and $p$-cymene $(15.02 \pm 1.02 \%$ and $11.51 \pm 0.97 \%)$, respectively. Microdilution assay was used to evaluate the antimicrobial property of EOs against Staphylococcus aureus (ATCC 25923), clinical isolate Methicillin-Resistant Staphylococcus aureus (MRSA), Enterococcus faecium (ATCC 700221) Klebsiella pneumoniae (ATCC 13883), Proteus vulgaris (ATCC 700221), Escherichia coli (ATCC 25922) and Pseudomonas aeruginosa (ATCC 27853) and Candida albicans (ATCC-90028). With a MIC of $0.135 \mu \mathrm{g} / \mathrm{mL}$, the EOs has the most potent antibacterial action against K. pneumonia. Both EOs display good antifungal efficacy against C. albicans, with a MIC value of $0.75 \mu \mathrm{g} / \mathrm{mL}$, which was better than that of Fluconazole's (positive control, MIC $=1.56 \mu \mathrm{g} / \mathrm{mL}$ ). The antioxidant capacity of EOs extracted from air-dried and fresh $S$. nabateorum was determined using the DPPH assay, with $\mathrm{IC}_{50}$ values of $4.78 \pm 0.41$ and $5.37 \pm 0.40 \mu \mathrm{g} / \mathrm{mL}$, respectively. The tested EOs showed significant cytotoxicity against Hela, HepG2, and COLO-205 cells, with $\mathrm{IC}_{50}$ values ranging from $82 \pm 0.98$ to $256 \pm 1.95 \mu \mathrm{g} / \mathrm{mL}$. The current work shows there is a possibility to use the S. nabateorum EOs for various applications.
\end{abstract}

Keywords: Satureja nabateorum; phytochemical profile; antibacterial; antifungal; antioxidant; anticancer

\section{Introduction}

Medicinal aromatic plants have been utilized for their preservative and healing properties since ancient times. Some of these characteristics are attributed to essential oils (EOs), which are produced as plant secondary metabolites. The bulk of essential oils are composed of terpenes, but they also include non-terpene components such as aldehydes, alcohols, esters, phenols, ethers, and ketones [1]. Whose physical purpose is to protect plants against bacteria, fungus, viruses, insects, and even herbivores by reducing their appetite for these plants [2]. EOs have been utilized as antimicrobials, sedatives, food preservatives, food additives, and cosmetics [2,3]. More than 250 types of essential oils at a value of 1.2 billion USD are traded yearly on the global market. This is in line with a cultural shift away from synthetic medicines and toward natural treatments for a wide range of illnesses. As a consequence, numerous research groups are studying essential oils and their primary components for antioxidant, anthelmintic, antibacterial, antifungal, antiviral, anticancer, antiparasitic, and insecticidal activities [4-6]. 
Antimicrobial drug resistance caused by the massive use of antibiotics and the harmful side effects of synthetic antimicrobial drugs has prompted scientists to search for novel antimicrobial lead compounds. Numerous studies have documented the antibacterial and antifungal activities of EOs, their chemical components, and the synergistic impact of their components [6-10]. In this regard, the use of EOs derived from Satureja species may be an effective strategy for reducing bacterial resistance. Azaz et al. reported that EOs extracted from Satureja hortensis, Satureja cuneifolia, Satureja thymbra, Satureja aintabensis, and Satureja macrantha possess significant antibacterial and antifungal potential [11].

The Lamiaceae family, popularly known as mint or sage, is a well-known flowering plant family with 236 genera and 7630 species distributed worldwide [8]. The genus $S a$ tureja (Thymbra) is one of the large family's genera, with approximately 200 species that grow naturally in the Middle East and Mediterranean European areas, as well as West Asia, North Africa, and South America [9]. Satureja thymbra, Satureja thymbrifolia, and Satureja nabateorum, of which the latter is only found in Palestine and Jordan, are the only three species of this genus known in Palestine. Thanks to the presence of physiologically active phytochemicals, Satureja EO affords the basis for a variety of biological and industrial applications with antimicrobial, antifungal, antioxidant, carminative, and digestive characteristics [12-15].

Satureja nabateorum Danin and Hedge is a 50-60 cm tall annual aromatic plant with white flowers. It is only found in smooth-faced sandstone crevices in Jordan's southwest (Edom) and the mountains of Tubas, Palestine, near the Dead Sea. It is similar to S. thymbrifolia, a species found in the desert east of Jerusalem that reaches down to the Dead Sea and is part of the $S$. sect. Zatarioideae [16,17]. In Bedouin veterinary medicine, the S. nabateorum plant is used to treat livestock diseases. In continuation of our ongoing research program concerning the identification of phytochemical composition and the assessment of biological activities of various wild-growing herbs in Palestine, we have considered investigating the chemical composition of S. nabateorum EO and assessing its antimicrobial, free radical scavenging activity. To the best of the author's knowledge, the phytochemical profile of S. nabateorum EO and its antimicrobial, antioxidant, and anticancer activity have never been studied before. Therefore, this research is aimed at (1) analyzing the chemical composition of EOs obtained from fresh and air-dried aerial parts of S. nabateorum, and (2) assessing their antioxidant, anticancer activity, and inhibitory activity on numerous microbial strains.

\section{Results and Discussion}

\subsection{Chemical Composition of S. nabateorum Essential Oils}

Microwave-assisted extraction of fresh and air-dried S. nabateorum aerial parts afforded light yellow oils. Table 1 contains the names, retention index, and percentages of identified compounds of both essential oils as obtained by GC-MS, as well as their analysis retention indices (RI). The GC chromatograms of EOs extracted from fresh and air-dried S. nabateorum are presented in Figures 1 and 2. A variability in yields of the EOs obtained from fresh $(1.80 \pm 0.09 \%)$ and air-dried $(1.55 \pm 0.07 \%)$ S. nabateorum samples was observed, with minor chemical composition variation. However, the yield percentage was calculated using the following equation: Yield $\%=$ mass of EO $/$ mass of plant $\times 100$.

Table 1. Chemical constituents of the essential oils from fresh and dry Satureja nabateorum.

\begin{tabular}{ccccc}
\hline & Component & RI & Dry, $\%$ & Fresh $\%$ \\
\hline 1 & $\alpha$-Thujene & 918 & $1.24 \pm 0.01$ & $1.06 \pm 0.12$ \\
\hline 2 & $\alpha$-Pinene & 930 & $0.65 \pm 0.002$ & $0.59 \pm 0.008$ \\
\hline 3 & Camphene & 952 & $0.23 \pm 0.006$ & $0.37 \pm 0.005$ \\
\hline 4 & Sabinene & 972 & $0.08 \pm 0.001$ & $0.15 \pm 0.001$ \\
\hline 6 & $\beta$-Pinene & 979 & $0.18 \pm 0.001$ & $0.20 \pm 0.02$ \\
\hline
\end{tabular}


Table 1. Cont.

\begin{tabular}{|c|c|c|c|c|}
\hline & Component & RI & Dry, \% & Fresh \% \\
\hline 7 & Myrcene & 991 & $1.47 \pm 0.01$ & $0.69 \pm 0.001$ \\
\hline 8 & $\delta$-2-Carene & 1003 & $0.23 \pm 0.002$ & $0.25 \pm 0.02$ \\
\hline 9 & $\alpha$-Terpinene & 1019 & $2.81 \pm 0.01$ & $2.68 \pm 0.98$ \\
\hline 10 & p-Cymene & 1023 & $15.02 \pm 1.02$ & $11.51 \pm 0.97$ \\
\hline 11 & Sylvesterine & 1029 & $0.68 \pm 0.009$ & $0.60 \pm 0.001$ \\
\hline 12 & Ocimene & 1033 & $0.60 \pm 0.008$ & $0.51 \pm 0.006$ \\
\hline 13 & $\gamma$-Terpinene & 1061 & $21.15 \pm 1.05$ & $20.65 \pm 1.12$ \\
\hline 14 & Terpinolene & 1087 & - & $0.09 \pm 0.002$ \\
\hline 15 & Linalool & 1098 & $1.69 \pm 0.05$ & $0.78 \pm 0.006$ \\
\hline 16 & cis-Thujone & 1103 & - & $0.17 \pm 0.003$ \\
\hline 17 & 3-Terpinen-1-ol & 1133 & - & $0.13 \pm 0.001$ \\
\hline 18 & (-)-Camphor & 1144 & - & $0.69 \pm 0.006$ \\
\hline 19 & Not identified & 1148 & - & $0.19 \pm 0.003$ \\
\hline 20 & Terpinen-4-ol & 1173 & $0.69 \pm 0.006$ & $0.17 \pm 0.002$ \\
\hline 21 & Nerol & 1228 & - & $0.15 \pm 0.001$ \\
\hline 22 & Thymol methylether & 1235 & $1.21 \pm 0.01$ & $0.76 \pm 0.005$ \\
\hline 23 & Carvacrol methylether & 1242 & $1.04 \pm 0.01$ & $3.44 \pm 0.01$ \\
\hline 24 & Linalool acetate & 1256 & - & $0.15 \pm 0.001$ \\
\hline 25 & Geranial & 1262 & $0.24 \pm 0.002$ & $2.91 \pm 0.01$ \\
\hline 26 & Neomenthyl acetate & 1266 & $0.24 \pm 001$ & - \\
\hline 27 & Isobornyl acetate & 1278 & - & $1.80 \pm 0.01$ \\
\hline 28 & Thymol & 1292 & $46.07 \pm 1.1$ & $40.64 \pm 1.21$ \\
\hline 29 & $\alpha$-Cubebene & 1345 & - & $0.89 \pm 0.002$ \\
\hline 30 & $\alpha$-Cupaene & 1377 & - & $0.25 \pm 0.004$ \\
\hline 31 & $\beta$-Cubebene & 1383 & - & $0.25 \pm 0.002$ \\
\hline 32 & $\beta$-Caryophyllene & 1424 & $2.78 \pm 0.006$ & $2.85 \pm 0.02$ \\
\hline 33 & $\alpha$-Caryophyllene & 1457 & $0.14 \pm 0.003$ & $0.16 \pm 0.001$ \\
\hline 34 & Geranyl propanoate & 1471 & $0.38 \pm 0.001$ & $0.30 \pm 0.01$ \\
\hline 35 & Muurolene & 1476 & $0.11 \pm 0.006$ & - \\
\hline 36 & Germacrene D & 1482 & $0.54 \pm 0.003$ & $1.14 \pm 0.07$ \\
\hline 37 & $\alpha$-Muurolene & 1497 & $0.07 \pm 0.001$ & $0.13 \pm 0.06$ \\
\hline 38 & Germacrene A & 1508 & $0.07 \pm 0.007$ & $0.36 \pm 0.21$ \\
\hline 39 & $\gamma$-Cadinene & 1514 & $0.16 \pm 0.006$ & $0.12 \pm 0.03$ \\
\hline 40 & $\delta$-Cadinene & 1528 & $0.22 \pm 0.001$ & $0.09 \pm 0.001$ \\
\hline 41 & Germacrene B & 1552 & $0.04 \pm 0.001$ & $0.26 \pm 0.004$ \\
\hline 42 & Caryophellene oxide & 1580 & $0.07 \pm 0.001$ & $0.10 \pm 0.002$ \\
\hline & Total & & 99.56 & 98.64 \\
\hline \multicolumn{5}{|c|}{ Grouped Compounds } \\
\hline & Monoterpene hydrocarbons & & 47.58 & 47.20 \\
\hline & Phenolic monoterpenes & & 48.32 & 44.84 \\
\hline & Sesquiterpene hydrocarbon & & 3.66 & 6.60 \\
\hline
\end{tabular}




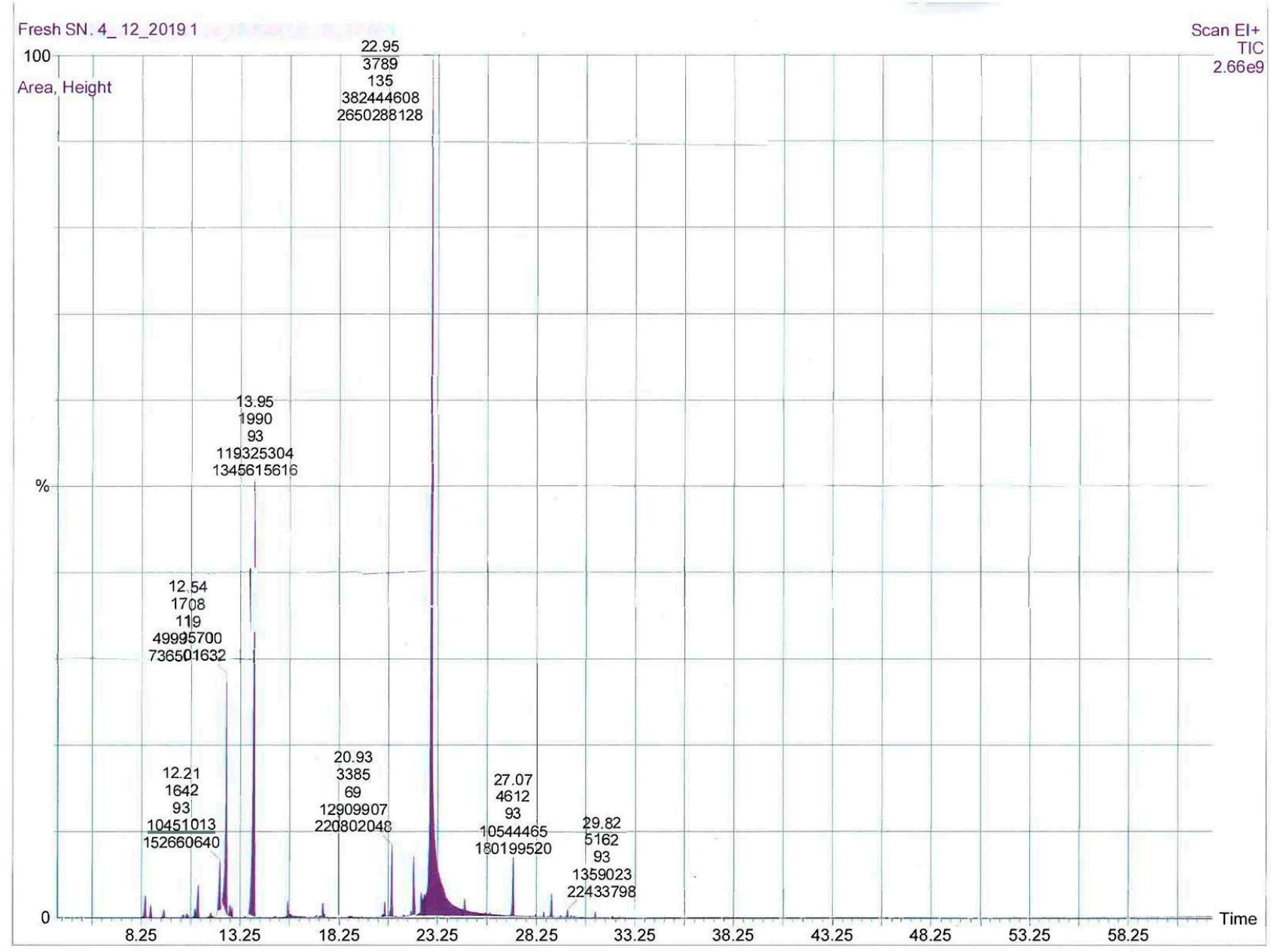

Figure 1. GC-MS chromatogram of the essential oils from fresh S. nabateorum.

GC-MS allowed us to identify a total of 42 compounds in the investigated EOs of $S$. nabateorum, accounting for around $99 \%$ as relative to peak area, with thymol $(46.07 \pm 1.1$ and $40.64 \pm 1.21 \%), \gamma$-terpinene $(21.15 \pm 1.05 \%$ and $20.65 \pm 1.12 \%)$, and $p$-cymene $(15.02 \pm 1.02 \%$ and $11.51 \pm 0.97 \%)$ being the main components of the EOs, respectively (Table 1 and Figure 1). Both EOs of S. nabateorum contained a high concentration of phenolic monoterpenes and monoterpenes (around 95\%) and a very low concentration of sesquiterpenes. Significant differences were observed when the main components of S. nabateorum were compared to those of previously examined Satureja species. In contrast to other Satureja plants, carvacrol, a constitutional isomer of thymol, was not identified in the EO of $S$. nabateorum. Carvacrol was found to be the most prevalent component in most Satureja species' EOs (27.24-88.71\%), followed by $\gamma$-terpinene (3.18-23.20\%) and $p$-cymene $(2.77-13.34 \%)$ [17]. 


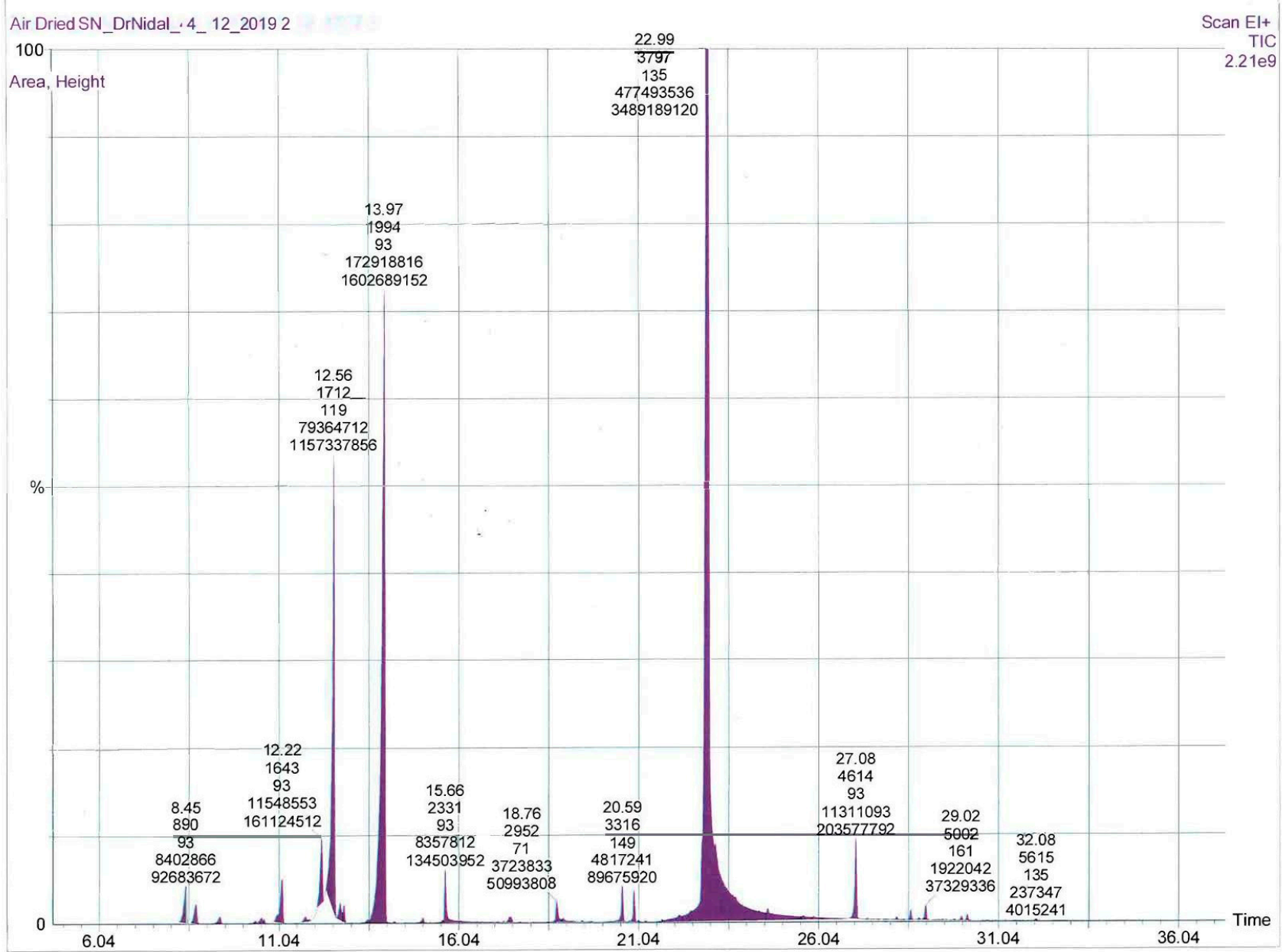

Figure 2. GC-MS chromatogram of the essential oils from air-dried S. nabateorum.

\subsection{Antimicrobial Activity of EOs from Fresh and Air-Dried S. nabateorum}

In this investigation, EOs extracted from fresh and air-dried S. nabateorum display similar antibacterial activity against all tested microbial strains. As shown in Table 2, S. nabateorum EOs display greater antibacterial activity against K. pneumonia, S. aureus, E. faecium, and E. coli (MIC $=0.135-2.25 \mu \mathrm{g} / \mathrm{mL})$ than ampicillin $(\mathrm{MIC}=1.00-3.12 \mu \mathrm{g} / \mathrm{mL})$, an antibiotic used to prevent and cure a variety of bacterial infections. The investigated EOs, on the other hand, exhibit antibacterial activity against $P$. aeruginosa, and MRSA clinical isolate with MIC values ranging from $6.25-12.50 \mu \mathrm{g} / \mathrm{mL}$, which was comparable to that of ciprofloxacin (MIC $=3.12-12.50 \mu \mathrm{g} / \mathrm{mL}$ ). EOs obtained from an air-dried sample exhibit greater antibacterial activity against MRSA $(\mathrm{MIC}=6.25 \mu \mathrm{g} / \mathrm{mL})$ than ciprofloxacin $(\mathrm{MIC}=12.5 \mu \mathrm{g} / \mathrm{mL})$.

Giweli et al. reported that $S$. thymbra EO exhibits antibacterial activity against B. cereus, M. flavus, S. aureus, L. monocytogenes, E. coli, P. aeruginosa, P. mirabilis, and S. typhimurium with MIC values ranging from $0.001-0.1 \mathrm{mg} / \mathrm{mL}$ [18]. Furthermore, Markovic et al. [19] reported that $S$. thymbra EO displayed greater antibacterial activity than streptomycin (positive control) against Gram-positive bacteria (B. cereus, S. aureus, M. flavus, and L. monoytogenes) and Gram-negative bacteria (P. aeruginosa, E. faecalis, S. Typhimurium, and E. coli) with MIC values ranging from $0.6-5.0 \mu \mathrm{g} / \mathrm{mL}$, of which $B$. cereus was the most sensitive bacteria and L. monoytogenes was the most resistant bacteria strain. Chorianopoulos et al. reported that S. thymbra L., S. spinose, and S. parnassica ssp. Parnassica possess antibacterial properties that outperform Origanum and Thymus species EOs against five foodborne bacteria, namely E. coli, S. enteritidis, S. aureus, L. monocytogenes, and B. cereus [20]. 
Table 2. Antibacterial and antifungal properties of the essential oils of S. nabateorum (MIC values in $\mu \mathrm{g} / \mathrm{mL})$.

\begin{tabular}{|c|c|c|c|c|c|c|c|c|}
\hline & S. aureus & E. faecium & E. coli & P. aeruginosa & K. pneumoniae & P. vulgaris & MRSA & C. albicans \\
\hline Source & ATCC 25923 & ATCC 700221 & ATCC 25922 & ATCC 27853 & ATCC 13883 & ATCC 700221 & $\begin{array}{l}\text { Clinically } \\
\text { diagnosed }\end{array}$ & ATCC 90028 \\
\hline Fluconazole & ND & ND & ND & ND & ND & ND & ND & 1.56 \\
\hline Ampicillin & $3.12 \pm 0.06$ & $1.56 \pm 0.01$ & $3.12 \pm 0.01$ & ND & $1 \pm 0.01$ & $18 \pm 0.91$ & ND & ND \\
\hline Ciprofloxacin & $0.78 \pm 0.01$ & $0.78 \pm 0.01$ & $1.56 \pm 0.08$ & $3.12 \pm 0.1$ & $0.125 \pm 0.02$ & $15 \pm 0.68$ & $12.50 \pm 0.58$ & ND \\
\hline $\begin{array}{c}\text { Fresh } S \text {. } \\
\text { nabateorum EO }\end{array}$ & $0.80 \pm 0.01$ & $1.25 \pm 0.03$ & $2.25 \pm 0.01$ & $6.25 \pm 0.61$ & $0.135 \pm 0.04$ & $22 \pm 1.02$ & $12.50 \pm 0.61$ & $0.75 \pm 0.05$ \\
\hline $\begin{array}{c}\text { Air-dried S. } \\
\text { nabateorum EO }\end{array}$ & $0.85 \pm 0.01$ & $1.25 \pm 0.05$ & $2.25 \pm 0.02$ & $12.50 \pm 1.31$ & $0.135 \pm 0.01$ & $22 \pm 1.13$ & $6.25 \pm 0.97$ & $0.75 \pm 0.05$ \\
\hline
\end{tabular}

MIC: minimum inhibitory concentration $(\mu \mathrm{g} / \mathrm{mL})$; ND: Not detected.

Both tested EOs display substantial fungicidal activity against $C$. albicans, with MICs values of $0.75 \mu \mathrm{g} / \mathrm{mL}$, which was better than that of the positive control, fluconazole $(\mathrm{MIC}=1.56 \mu \mathrm{g} / \mathrm{mL})$. Geweli et al. reported that $S$. thymbra EOs display very strong antifungal activities with MIC values ranging from $1.00-25.00 \mu \mathrm{g} / \mathrm{mL}$ against $P$. funiculosum, P. ochrochloron, A. flavus, A. ochraceus, A. niger, A. fumigatus, T. viride, and C. albicans [18], of which $P$. ochrochloron was the most sensitive fungus, with a MIC value of $1 \mu \mathrm{g} / \mathrm{mL}$, whereas C. albicans (MIC $=25 \mu \mathrm{g} / \mathrm{mL}$ ) was the most resistant species. EOs used in this investigation outperformed $S$. thymbra in terms of antimicrobial activity. This significant antibacterial and antifungal efficacy may be attributed to the high concentrations of thymol $(46.07 \%), \gamma$-terpinene $(21.15 \%)$, and $p$-cymene $(15.02 \%)$, as well as to their synergistic impact. Chorianopoulos et al. found that S. thymbra EO, which contains only $42.39 \%$ thymol and carvacrol, possess higher antimicrobial activity against bacteria and fungi as opposed to EOs containing $88.71 \%$ thymol and carvacrol, such as Origanum vulgare ssp. hirtum (Link) [17]. This suggests that the antimicrobial activity is not purely attributed to the high percentage of these phenols, but that other minor active constituents play a part as well.

\subsection{Antioxidant Activity}

The antioxidant property of fresh and air-dried S. nabateorum EOs was determined using the DPPH free radical scavenging assay, which is widely used to estimate the antioxidant potentials of plant EOs. Trolox, an artificial antioxidant, was used as a positive control. The findings showed that both EOs extracted from fresh and air-dried S. nabateorum have a dose-dependent free radical scavenging property (Figure 3).

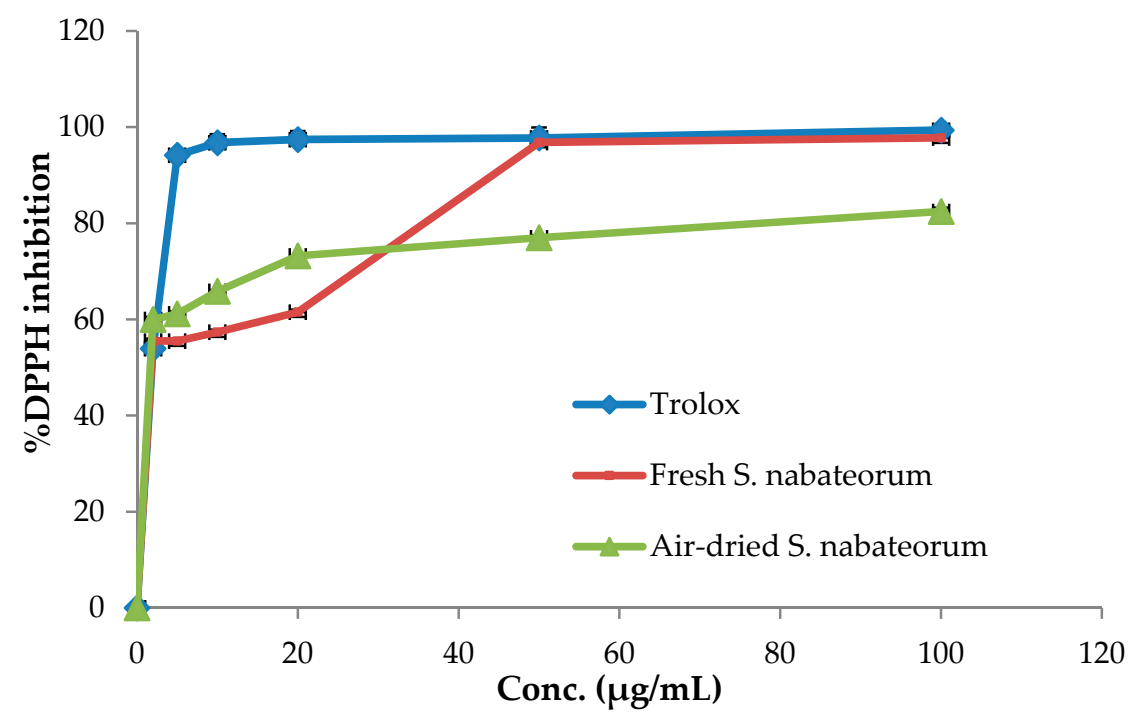

Figure 3. DPPH inhibitory activity by fresh and air-dried S. nabateorum EOs and Trolox. 
The antioxidant outcomes revealed that air-dried $S$. nabateorum EOs display high antioxidant potential, as seen from the concentrations at which $50 \%$ of radicals have been quenched $\left(\mathrm{IC}_{50}=4.78 \pm 0.41 \mu \mathrm{g} / \mathrm{mL}\right)$, being slightly better than the antioxidant activity of EO extracted from fresh $S$. nabateorum aerial parts $\left(\mathrm{IC}_{50}=5.37 \pm 0.40 \mu \mathrm{g} / \mathrm{mL}\right)$ and weaker than that of Trolox $\left(\mathrm{IC}_{50}=2.23 \pm 1.57 \mu \mathrm{g} / \mathrm{mL}\right)$. The current study's observations are in agreement with those of Elgndi et al. [21], who found that $S$. montana EO has significant antioxidant activity with an $\mathrm{IC}_{50}$ value of $5.05 \pm 1.52 \mu \mathrm{g} / \mathrm{mL}$. Aghbash et al. reported that $S$. macrantha EOs at various growth stages show remarkable oxidative activities ranging from $12.14 \pm 0.63-21.85 \pm 1.02 \mu \mathrm{g} / \mathrm{mL}$, which are less active than S. nabateorum [22]. Geweli et al. documented that $S$. thymbra $\mathrm{EO}$ possesses antioxidant activity with an $\mathrm{IC}_{50}$ value of $96.7 \mu \mathrm{g} / \mathrm{mL}$, which is much weaker than that of S. nabateorum EO [18]. Ghotbabadi et al. [23] assessed the antioxidant capacity of $S$. sahendica EOs at three phenological stages and found that EO obtained at the pre-flowering stage has the highest radical scavenging activity with an $\mathrm{IC}_{50}$ value of $7.85 \pm 0.06 \mu \mathrm{g} / \mathrm{mL}$, being slightly weaker than that of $S$. nabateorum EOs.

The existence of phenolic monoterpenes thymol and carvacrol, as well as their precursors $\gamma$-terpinene and $p$-cymene, which behave synergistically as radical scavengers, is compatible with the radical scavenging activity of Satureja EOs [24,25]. EO extracted from air-dried $S$. nabateorum, in particular, exhibits higher potential antioxidant activity than the Satureja montana EO $(5.05 \pm 1.25 \mu \mathrm{g} / \mathrm{mL})$ which is almost the same potentials as the current study fresh $S$. nabateorum $\mathrm{EO}(5.37 \pm 0.4 \mu \mathrm{g} / \mathrm{mL})$ [21].

\subsection{Cytotoxic Characters}

The cell viability of tested EOs was evaluated by the cells' ability to metabolically convert MTT to a formazan dye after $24 \mathrm{~h}$ of exposure to EO at different doses ranging from 0.025 to $6.4 \mathrm{mg} / \mathrm{mL}$. The cytotoxic activity ( $\mathrm{IC}_{50}$ values) of both tested $S$. nabateorum EOs are shown in Table 3. Both essential oils display cytotoxic activity against MCF-7, COLO-205, HeLa, and HepG2 cancer cell lines in a dose-dependent manner, with $\mathrm{IC}_{50}$ values ranging from $82 \pm 0.98$ to $1090 \pm 3.25 \mu \mathrm{g} / \mathrm{mL}$ (Table 3). EOs obtained from fresh S. nabateorum exhibit the highest cytotoxic effect against HeLa and HepG2 cancer cells, with $\mathrm{IC}_{50}$ values of $82 \pm 0.98$ and $90 \pm 0.77 \mu \mathrm{g} / \mathrm{mL}$, respectively, while EOs extracted from air-dried $S$. nabateorum exhibit the highest cytotoxic action against HeLa cancer cells, with $\mathrm{IC}_{50}$ values of $89 \pm 0.74$ and134.3 $\pm 1.2 \mu \mathrm{g} / \mathrm{mL}$, respectively. Elgndi et al. [21] reported that S. montana EO, which is mostly comprised of carvacrol $(57 \%)$ has cytotoxic action against HeLa cells with an $\mathrm{IC}_{50}$ value of $88.25 \pm 10.85 \mu \mathrm{g} / \mathrm{mL}$, which is consistent with the findings of the present investigation. According to Yousefzadi et al., S. khuzistanica EO significantly reduced cell viability of MCF7 cells in a dose-dependent manner, with an $\mathrm{IC}_{50}$ value of $125 \mu \mathrm{g} / \mathrm{mL}$, which was better than S. nabateorum EOs. The cytotoxic effect is believed to be due to the high amount of carvacrol, which accounts for $93 \%$ of the total composition of S. khuzistanica EO. Yousefzadi found that $S$. sahendica EO exhibits significant cytotoxicity against MCF7, Vero, SW480, and JET 3 with $\mathrm{IC}_{50}$ values of 15.6, 15.6, 125, and $250 \mu \mathrm{g} / \mathrm{mL}^{-1}$, respectively [26].

Table 3. Cytotoxic activity $\mathrm{IC}_{50}$ values of the EOs obtained from fresh and air-dried S. nabateorum compared with Doxorubicin.

\begin{tabular}{ccccc}
\hline & \multicolumn{3}{c}{ IC $_{\mathbf{5 0}}(\boldsymbol{\mu g} / \mathbf{m L})$} & Values against Different Cancer Cell Lines \\
\hline Cells & MCF-7 & COLO-205 & HeLa & HepG2 \\
\hline Air-dried S. nabateorum & $1090 \pm 3.25$ & $134.3 \pm 1.2$ & $89 \pm 0.74$ & ND \\
Fresh S. nabateorum & $930 \pm 1.25$ & $256 \pm 1.95$ & $82 \pm 0.98$ & $90 \pm 0.77$ \\
DOX & $3 \pm 0.89$ & $5 \pm 0.78$ & $9.5 \pm 1.0$ & $25.43 \pm 1.73$ \\
\hline
\end{tabular}




\section{Materials and Methods}

\subsection{Plant Material}

Aerial parts of S. nabateorum were gathered from the Jericho mountains in Palestine, which overlook the Dead Sea, before blooming in May 2019. The plant's identity was verified by Dr. Nidal Jaradat and the voucher specimen herbarium marked Pharm-PCT1633 was kept in the Herbal Products Laboratory at An-Najah National University-NablusPalestine. The plant was washed with distilled water, dried in the shade for two weeks at $25 \pm 2{ }^{\circ} \mathrm{C}$ and $55 \pm 5 \mathrm{RH}$ humidity, milled with a mechanical grinder, and stored in paper bags.

\subsection{Extraction of the Essential Oils}

The EOs were extracted from fresh and air-dried aerial parts of S. nabateorum using the Ultrasonic-Microwave apparatus, as previously described for other Lamiaceae species [27]. A $1 \mathrm{~L}$ round-bottom flask containing a suspension of dried plant powder $(50 \mathrm{~g})$ in distilled water $(0.5 \mathrm{~L})$ was placed in the apparatus and attached to the Clevenger device. The microwave power was set at $800 \mathrm{~W}$, and the EO was extracted for $20 \mathrm{~min}$ at $90{ }^{\circ} \mathrm{C}$. The experiment was repeated three times under the same conditions. The combined extracts were dried with calcium chloride and stored in a sealed vial at $2-8{ }^{\circ} \mathrm{C}$.

\subsection{Qualitative and Quantitative Analysis}

For gas chromatographic experiments, a Perkin Elmer Elite-5-MS fused silica capillary column $(30 \mathrm{~m} \times 0.25 \mathrm{~mm}$, film thickness $0.25 \mathrm{~m})$ was used. The helium flow rate was set at $1.1 \mathrm{~mL} / \mathrm{min}$. The injector temperature was set at $250{ }^{\circ} \mathrm{C}$, and the oven temperature set to $50{ }^{\circ} \mathrm{C}$ for $5 \mathrm{~min}$ before ramping up to $280{ }^{\circ} \mathrm{C}$, at a rate of $4.0^{\circ} \mathrm{C} / \mathrm{min}$. The total run time was $62.50 \mathrm{~min}$, with a solvent delay of 0 to $4.0 \mathrm{~min}$. The MS spectra in scan mode was between minute 4 to minute 62.5 and had a mass range of 50.00 to $300.00 \mathrm{~m} / \mathrm{z}$. The composition percentages were determined using the area data and rounded to the second decimal place. The components of $S$. nabateorum EO were detected by comparing their respective Kovats retention index (RI) values to those published in the literature, as well as by comparing the components' mass spectra $\left(\mathrm{M}^{+}\right.$, and fragmentation pattern) to those in the National Institute of Standards and Technology (NIST08) MS data Center, and by co-injection with authentic compounds such as thymol and carvacrol. n-Alkanes $\left(C_{7}-C_{30}\right)$ mixture was employed for the determination retention indices (RI).

\subsection{Antimicrobial Screening}

\subsubsection{Microbial Isolates}

A broth microdilution method was utilized for evaluation of the antibacterial property of $S$. nabateorum EOs against seven bacterial strains which were obtained from the American Type Culture Collection (ATCC) and one diagnostically confirmed species. The Gramnegative strains were Pseudomonas aeruginosa (ATCC 9027), Escherichia coli (ATCC 25922), Klebsiella pneumonia, (ATCC 13883), and Proteus vulgaris (ATCC 8427). Gram-positive strains included Enterococcus faecium (ATCC 700221), Staphylococcus aureus (ATCC 25923), and Methicillin-Resistant Staphylococcus aureus (MRSA). The antifungal activity of the investigated EOs was evaluated against the growth of C. albicans (ATCC 90028).

\subsubsection{Antimicrobial Test}

Using broth microdilution, the antibacterial efficacy of fresh and air-dried S. nabateorum EOs was determined [28]. The studied microorganisms were cultured separately on sterilized Muller-Hinton broth for $24 \mathrm{~h}$ at $37^{\circ} \mathrm{C}$ using the streak plate process. A test tube containing $5 \mathrm{~mL}$ of nutrient broth was inoculated with bacterial strain from overnight colonies under aseptic conditions. The microorganism suspension was shacked in the test tubes. The turbidity of the bacterial suspension was modified to meet the turbidity standard $0.5 \mathrm{McFarland}\left(1.5 \times 10^{8} \mathrm{cfu} / \mathrm{mL}\right)$ and was subjected to three-fold dilution by 
mixing $1 \mathrm{~mL}$ of the suspension with $2 \mathrm{~mL}$ of the nutrient broth to achieve turbidity of $0.5 \times 10^{8} \mathrm{cfu} / \mathrm{mL}$. The Turbidity of the bacterial suspension was measured at $600 \mathrm{~nm}$.

The EOs were dissolved separately in 10\% DMSO (Riedel-De-Han, Germany) to a concentration of $200 \mu \mathrm{g} / \mathrm{mL}$. Each of the two solutions was serially micro-diluted (2-fold) in sterile Mueller Hinton broth. Next, $100 \mu \mathrm{L}$ of Mueller Hinton broth was placed into each well of the 96-well microtiter plate (Greiner bio-one, North America), followed by the addition of $100 \mu \mathrm{L}$ of the $\mathrm{EO}$ dilution to wells of the first column, making the total volume in each well of the first column $200 \mu \mathrm{L}$. Thereafter, starting from the first column, serial dilutions up to column \#11 were performed by transferring $100 \mu \mathrm{L}$ of dispensed suspension from the previous to the next well, and $100 \mu \mathrm{L}$ of the suspension was removed from the 11th column. Wells in column 12 were kept free from EOs and considered as a positive control. Subsequently, $1 \mu \mathrm{L}$ of the bacterial suspension was added to each well except wells \#11, which was considered a negative control for microbial growth. Finally, the plate was incubated for $24 \mathrm{~h}$ at $37^{\circ} \mathrm{C}$ (Incubator-Nuve, Turkey). For all bacteria tested in the current work, ciprofloxacin, ampicillin, and fluconazole were used as positive controls in the current study. The EOs were tested in triplicate.

\subsection{Free Radical Scavenging Activity}

The antioxidant activity of the two EOs was assessed based on their ability to scavenge the free radical diphenyl-1-picrylhydrazyl (DPPH) [1]. A stock solution $(1 \mathrm{mg} / \mathrm{mL})$ was prepared from S. nabateorum EOs by dissolving $100 \mathrm{mg}$ of each EO in methanol $(100 \mathrm{~mL})$, of which serial dilutions to obtain different concentrations $(1,2,5,10,20,50$, and $100 \mu \mathrm{g} / \mathrm{mL})$ was made. Next, $1 \mathrm{~mL}$ of the diluted $\mathrm{EO}$ and $1 \mathrm{~mL}$ of methanol were mixed with $1 \mathrm{~mL}$ of DPPH methanol solution $(0.002 \%)$. After $30 \mathrm{~min}$ incubation at room temperature in a dark place, the absorbance of the samples was recorded at $517 \mathrm{~nm}$ against the control using a UV-visible spectrophotometer. A blank solution was prepared by replacing the EO solution with neat methanol. The inhibition percentage was calculated according to the following equation.

$$
I(\%)=\frac{[\text { ABSblank }- \text { ABStest }]}{[\text { ABSblank }]} \times 100 \%
$$

The $\mathrm{IC}_{50}(\mu \mathrm{g} / \mathrm{mL})$ values were calculated as the concentration, that scavenges $50 \%$ of DPPH radical. The same conditions were used for evaluating the inhibition percentage and $\mathrm{IC}_{50}$ of Trolox as a positive control. The antioxidant activity of the EOs was conducted in triplicate.

\subsection{Cell Culture and Cytotoxicity Assay}

The breast (MCF-7), liver (HepG2), cervix (HeLa), and colon (COLO 205) cancer cells were cultured separately in RPMI-1640 media, which was supplemented with $1 \%$ l-glutamine (Sigma, UK), 1\% Penicillin/Streptomycin, and 10\% fetal bovine serum. The cells were fully grown in a humidified environment with $5 \% \mathrm{CO}_{2}$ at $37^{\circ} \mathrm{C}$ and seeded at $2.6 \times 10^{4}$ cells /well in a 96-well plate. After $24 \mathrm{~h}$, cells were incubated with various concentrations of the tested EOs for $24 \mathrm{~h}$. Cells viability test was assessed by CellTilter $96{ }^{\circledR}$ Aqueous One Solution Cell Proliferation (MTS) Assay according to the manufacturer's instructions (Promega Corporation, Madison, WI, USA). At the end of the treatment, $20 \mu \mathrm{L}$ of MTS solution per $100 \mu \mathrm{L}$ of media was added to each well and incubated for $2 \mathrm{~h}$ at $37^{\circ} \mathrm{C}$. Absorbance was measured at $490 \mathrm{~nm}$.

\subsection{Statistical Analysis}

All the conducted experiments were carried out in triplicate and the obtained results were expressed as mean $\pm \mathrm{SD}$ and the results were considered significant when the $p$-value was less than 0.05 . 


\section{Conclusions}

The GC-MS analysis of the fresh and air-dried S. nabateorum EOs revealed that thymol was the major component, followed by $\gamma$-terpinene and $\mathrm{p}$-cymene. Both oils exhibited potential antioxidant capacity and cytotoxic activity against HeLa and HepG2 cancer cells. In addition, the investigated oils showed remarkable antimicrobial effect, which may provide a potential alternative to chemical fungicides and bactericides, as well as antioxidants, and could find applications as natural preservatives and conservation agents in the food and/or cosmetic industries. Briefly, the investigated two EOs revealed a slight variation in the phytochemical compositions and biological activities. Further studies are required to isolate the biologically active compounds from these oils and to approve these effects in vivo and investigate their mechanism of action.

Author Contributions: Conceptualization, N.A.-M. and N.J.; methodology, N.A.-M. and N.J.; software, N.A.-M. and N.J.; validation, N.A.-M. and N.J.; formal analysis, N.A.-M. and N.J.; investigation, N.A.-M. and N.J.; resources, N.A.-M. and N.J.; data curation, N.A.-M. and N.J.; writing-original draft preparation, N.A.-M. and N.J.; writing-review and editing, N.A.-M. and N.J.; visualization, N.A.-M. and N.J.; supervision, N.A.-M. and N.J. All authors have read and agreed to the published version of the manuscript.

Funding: This research received no external funding.

Institutional Review Board Statement: Not applicable.

Informed Consent Statement: Not applicable.

Data Availability Statement: All data is contained within the article.

Acknowledgments: The authors wish to thank An-Najah National University.

Conflicts of Interest: The authors declare that there are no conflicts of interest.

Sample Availability: Samples of the compounds are not available from the authors.

\section{References}

1. Jaradat, N.; Al-Maharik, N. Fingerprinting, Antimicrobial, Antioxidant, Anticancer, Cyclooxygenase and Metabolic Enzymes Inhibitory Characteristic Evaluations of Stachys viticina Boiss. Essential Oil. Molecules 2019, 24, 3880. [CrossRef]

2. Bakkali, F.; Averbeck, S.; Averbeck, D.; Idaomar, M. Biological effects of essential oils-A review. Food Chem. Toxicol. 2008, 46, 446-475. [CrossRef]

3. Pandey, A.K.; Kumar, P.; Singh, P.; Tripathi, N.N.; Bajpai, V.K. Essential oils: Sources of antimicrobials and food preservatives. Front. Microbiol. 2017, 7, 2161. [CrossRef] [PubMed]

4. Jaradat, N.; Adwan, L.; K'aibni, S.; Shraim, N.; Zaid, A.N. Chemical composition, anthelmintic, antibacterial and antioxidant effects of Thymus bovei essential oil. BMC Complement. Altern. Med. 2016, 16, 418. [CrossRef]

5. Chouhan, S.; Sharma, K.; Guleria, S. Antimicrobial activity of some essential oils-Present status and future perspectives. Medicines 2017, 4, 58. [CrossRef] [PubMed]

6. Burt, S. Essential oils: Their antibacterial properties and potential applications in foods-A review. Int. J. Food Microbiol. 2004, 94, 223-253. [CrossRef]

7. Tepe, B.; Cilkiz, M. A pharmacological and phytochemical overview on Satureja. Pharm. Biol. 2016, 54, 375-412. [CrossRef]

8. Akthar, M.S.; Degaga, B.; Azam, T. Antimicrobial activity of essential oils extracted from medicinal plants against the pathogenic microorganisms: A review. Issues Bio. Sci. Pharmacol. Res. 2014, 2, 1-7.

9. Al-Mariri, A.; Safi, M. In vitro antibacterial activity of several plant extracts and oils against some gram-negative bacteria. Iran. J. Med. Sci. 2014, 39, 36-43.

10. Lang, G.; Buchbauer, G. A review on recent research results (2008-2010) on essential oils as antimicrobials and antifungals. A review. Flavour Fragr. J. 2012, 27, 13-39. [CrossRef]

11. Azaz, A.D.; Kürkcüoglu, M.; Satil, F.; Can Baser, K.H.; Tümen, G. In vitro antimicrobial activity and chemical composition of some Satureja essential oils. Flavour Fragr. J. 2005, 20, 587-591. [CrossRef]

12. Khoury, M.; Stien, D.; Eparvier, V.; Ouaini, N.; El Beyrouthy, M. Report on the Medicinal Use of Eleven Lamiaceae Species in Lebanon and Rationalization of Their Antimicrobial Potential by Examination of the Chemical Composition and Antimicrobial Activity of Their Essential Oils. Evid. Based Complement. Altern. Med. 2016, 2016, 2547169. [CrossRef]

13. Maccelli, A.; Vitanza, L.; Imbriano, A.; Fraschetti, C.; Filippi, A.; Goldoni, P.; Maurizi, L.; Ammendolia, M.G.; Crestoni, M.E.; Fornarini, S. Satureja montana L. Essential oils: Chemical profiles/phytochemical screening, antimicrobial activity and o/w nanoemulsion formulations. Pharmaceutics 2020, 12, 7. [CrossRef] 
14. Ćavar, S.; Maksimović, M.; Šolić, M.E.; Jerković-Mujkić, A.; Bešta, R. Chemical composition and antioxidant and antimicrobial activity of two Satureja essential oils. Food Chem. Toxicol. 2008, 111, 648-653. [CrossRef]

15. Momtaz, S.; Abdollahi, M. An update on pharmacology of Satureja species; from antioxidant, antimicrobial, antidiabetes and anti-hyperlipidemic to reproductive stimulation. Int. J. Pharmacol. 2010, 6, 346-353. [CrossRef]

16. Danin, A.; Hedge, I.C. Contributions to the flora of Jordan 2. A new species of Satureja (Labiatae) and some new records. Willdenowia 1998, 28, 135-142. [CrossRef]

17. BräuChler, C. Delimitation and revision of the genus Thymbra (Lamiaceae). Phytotaxa 2018, 369, 15-27. [CrossRef]

18. Giweli, A.; Džamić, A.M.; Soković, M.; Ristić, M.S.; Marin, P.D. Antimicrobial and antioxidant activities of essential oils of Satureja thymbra growing wild in Libya. Molecules 2012, 17, 4836-4850. [CrossRef] [PubMed]

19. MArkOvIć, T.; Chatzopoulou, P.; Šiljegović, J.; Nikolić, M.; Glamočlija, J.; Ćirić, A.; Soković, M. Chemical analysis and antimicrobial activities of the essential oils of Satureja thymbra L. and Thymbra spicata L. and their main components. Arch. Biol. Sci. 2011, 63, 457-464. [CrossRef]

20. Chorianopoulos, N.; Kalpoutzakis, E.; Aligiannis, N.; Mitaku, S.; Nychas, G.-J.; Haroutounian, S.A. Essential oils of Satureja, Origanum, and Thymus species: Chemical composition and antibacterial activities against foodborne pathogens. J. Agric. Food Chem. 2004, 52, 8261-8267. [CrossRef]

21. Elgndi, M.A.; Filip, S.; Pavlić, B.; Vladić, J.; Stanojković, T.; Žižak, Ž.; Zeković, Z. Antioxidative and cytotoxic activity of essential oils and extracts of Satureja montana L., Coriandrum sativum L. and Ocimum basilicum L. obtained by supercritical fluid extraction. J. Supercrit. Fluids 2017, 128, 128-137. [CrossRef]

22. Aghbash, B.N.; Pouresmaeil, M.; Dehghan, G.; Nojadeh, M.S.; Mobaiyen, H.; Maggi, F. Chemical composition, antibacterial and radical scavenging activity of essential oils from Satureja macrantha CA Mey. at different growth stages. Foods 2020, 9, 494. [CrossRef] [PubMed]

23. Ghotbabadi, F.S.; Alizadeh, A.; Zadehbagheri, M.; Kamelmanesh, M.M.; Shaabani, M. Phytochemical composition of the essential oil, total phenolic content, antioxidant and antimicrobial activity in Iranian Satureja sahendica Bornm. at different ontogenesis conditions. J. Med. Plant Res. 2012, 6, 3525-3534.

24. Vitali, L.A.; Beghelli, D.; Nya, P.C.B.; Bistoni, O.; Cappellacci, L.; Damiano, S.; Lupidi, G.; Maggi, F.; Orsomando, G.; Papa, F. Diverse biological effects of the essential oil from Iranian Trachyspermum ammi. Arab. J. Chem. 2016, 9, 775-786. [CrossRef]

25. Zhang, L.; Yang, Z.; Wei, J.; Su, P.; Pan, W.; Zheng, X.; Zhang, K.; Lin, L.; Tang, J.; Fang, Y. Essential oil composition and bioactivity variation in wild-growing populations of Curcuma phaeocaulis Valeton collected from China. Ind. Crops Prod. 2017, 103, 274-282. [CrossRef]

26. Yousefzadi, M.; Riahi-Madvar, A.; Hadian, J.; Rezaee, F.; Rafiee, R.; Biniaz, M. Toxicity of essential oil of Satureja khuzistanica: In vitro cytotoxicity and anti-microbial activity. J. Immunotoxicol. 2014, 11, 50-55. [CrossRef]

27. Jaradat, N.; Adwan, L.; Zaid, A.N.; K'aibni, S.; Arar, M. Composition, anticholinesterase and antipedicular activities of Satureja capitata L. volatile oil. Open Life Sci. 2020, 15, 60-67. [CrossRef]

28. Balouiri, M.; Sadiki, M.; Ibnsouda, S.K. Methods for in vitro evaluating antimicrobial activity: A review. J. Pharm. Anal. 2016, 6, 71-79. [CrossRef] 